\title{
Preface to the 2009 Edition
}

It is very gratifying that Racial Fault Lines has found a wide academic and lay audience and continues to make a valuable contribution to our understanding of race and ethnic relations in the United States. This book was initially written with two purposes in mind. First, it was intended as a contribution to our understanding of "race" as a sociohistorical concept whose fundamental meaning varies depending on time, place, and historical context. Second, it is a historically specific examination of the process of "racial formation"-or the way in which racial status is extended or conferred on various nationalities and ethnic groups.

California was chosen to illustrate that racial categories are historically contingent and fluid in their specific meaning and to highlight the important role that the Mexican population played in the process of racial formation. A central focus of this study was the specific racial status and structural placement of Mexicans in California as a result of the U.S.-Mexico War of $1846-48$. That monumental imperial enterprise was followed by the rapid displacement of the once powerful Mexican landholding class and its subsequent economic and political subordination in the new political order introduced after California's annexation by the United States. Mexicans' social displacement and initial racialization formed the central problematic and historical question underpinning this book.

I was surprised to learn that the Mexican "Californios" were formally accorded the same rights and privileges initially granted only to 
the white immigrant population that overran the territory upon the discovery of gold in 1848 . They were not positioned at the bottom of the new racial order imposed in California as the indigenous Indian, Asian, and black immigrant populations were. The reason for this, as I learned in the course of my historical investigation, was that Mexicans successfully asserted their claims to whiteness and were essentially granted an honorary white status. On the basis of this status, they were placed in a qualitatively different political and structural location in the new society introduced by the newly dominant European American population in the territory. Yet, while Mexicans may have been granted momentary political concessions through the Treaty of Guadalupe Hidalgo, which ratified the colonial conquest of the new American Southwest, their status was precarious and the privileges of "whiteness" were not always meaningfully extended.

The decline of the once powerful Mexican landholding class led to the rapid subordination of the entire Mexican population in California, and that reduced status was reinforced by subsequent Mexican migration after the turn of the century. By the early decades of the twentieth century, it was quite clear that Mexicans had been relegated to an inferior status in California that paralleled that of other groups socially defined as "nonwhite." Like the Chinese, Japanese, black, and Indian populations in the state, Mexicans were socially located in a "secondclass" social and political status that only served to elevate the position of the burgeoning European immigrant population of California. Political contestation over Mexicans' meaningful access to full citizenship rights in California continues to rage to this day.

It is the unanticipated ways that racial meaning and "whiteness" were conferred in California during the last half of the nineteenth century that lie at the heart of this historical study. By placing this racial formation process in historical and comparative context I have endeavored to illustrate the sociohistorical meaning of race in the construction of a new racial hierarchy in California. The explicit comparative framing of this process was beginning to emerge in importance in the fields of ethnic studies and the sociology of race and ethnicity at the time of the book's original publication in 1994. I am pleased that Racial Fault Lines has been useful to students and others in making sense of the historically contingent and fundamentally social nature of this racial categorization and the new structuring of racial inequality in California.

I will avoid the temptation to revisit the central arguments or to reframe and update the historical analysis at the heart of Racial Fault 
Lines. While I would have liked to extend the analysis further in time and provide a more comprehensive statewide analysis, this would have led to a different kind of book. I may take on this challenge in a more extended update of the book sometime in the future. In the meantime, I remain confident of the enduring value of my historical analysis and the utility of the comparative framing of race relations in California. While certainly much has changed since the last half of the nineteenth century, it is disquieting to reflect on the way that white supremacy remains a vibrant force in the state. Much of what I argue in Racial Fault Lines continues to have relevance in the contemporary period. It is for that reason that I look forward to Racial Fault Lines finding an ever-wider audience interested in the social nature of racial categories and hierarchies of inequality that underlie this contribution to the field.

San Francisco

June 2008 
